\title{
PROSES DESINFEKSI PADA PENGOLAHAN AIR LIMBAH DOMESTIK MENJADI AIR BERSIH SEBAGAI AIR BAKU AIR MINUM
}

\author{
Rhenny Ratnawati dan Sugito*)
}

\begin{abstract}
Abstrak
Permasalahan air bersih semakin berkembang akibat kerusakan lingkungan dan pencemaran air limbah domestik. Upaya pengolahan air limbah domestik dilakukan untuk mereduksi bahan organik dan logam-logam yang mencemari air permukaan sebagai bahan baku air bersih.Aplikasi Biofilter terpadukan dengan teknologi filtrasi berbasis multimedia filter dapat menghasilkan air bersih yang memenuhi standar sehingga menghemat energi proses dan biaya pengolahan. Air olahan dapat ditingkatkan sebagai air baku untuk air bersih dan air minum. Pada penelitian ini dilakukan kajian proses Desinfeksi pada pengolahan air limbah domestik menjadi air baku yang dapat dikembangkan menjadi air bersih dan air minum. Penelitian dilakukan secara terpadu menggunakan aplikasi Biofilter dengan Fltrasi dilanjutkan dengan proses Desinfeksi. Reaktor Biofilter tersusun secara terpadu dengan kombinasi reaktor anaerobik dan aerobik menggunakan media batu koral diameter 1-2 cm untuk optimalisasi removal bahan organik. Filtrasi dilakukan dengan menggunakan resin katio-anion, pasir silika dan manganess greensand. Desinfeksi menggunakan bahan Kaporit dengan dosis 100 ppm, 150 ppm, 200 ppm, 250 ppm, 300 ppm, 350 ppm, dan 400 ppm untuk menurunkan kandungan bakteri Escherecia Coli. Sampel air limbah yang digunakan adalah air limbah Puskesmas. Target yang ingin dicapai adalah untuk memperoleh air baku air bersih atau air minum dari air limbah domestik yang memenuhi baku mutu.Data kualitas air dianalisis di laboratorium menggunakan metode penelitian air secara lengkap untuk parameter fisik, kimia, dan mikrobiologis. Perbandingan parameter antara kualitas influen dan efluen menunjukkan kapasitas unjuk kerja reaktor dan proses desinfeksi. Hasil penelitian menunjukan bahwa pada pemberian kaporit dengan dosis 350 ppm dan 400 ppm telah diperoleh air olahan yang tidak mengandung bakteri Esherecia Coli sehingga memenuhi baku mutu kualitas air bersih sesuai Permenkes RI No 416/MENKES/PER/IX/1990 Hasil penelitian ini berupa air olahan memenuhi syarat yang dapat dimanfaatkan kembali (recycle) sehingga dapat menekan biaya operasional institusi yang menghasilkan air limbah.
\end{abstract}

Kata kunci : Air Bersih, Air Limbah Domestik, Biofilter, Desinfeksi, Filtrasi,

\section{PENDAHULUAN}

Peningkatan jumlah penduduk berdampak pada meningkatnya kebutuhan air bersih. Saat ini keberadaan air bersih semakin sulit diperoleh akibat penggundulan hutan dan pencemaran air. Musim kemarau yang lebih panjang pada tahun 2012 berdampak pada menurunnya kuantitas dan kualitas serta kontinuitas air bersih. Minimnya debir air bersih menyebabkan beban pencemaran semakin tinggi pada air permukaan. Buruknya sanitasi akan menyebabkan kualitas lingkungan yang berbahaya bagi kesehatan manusia, (Hermana, 2008). Pencemaran air limbah domestik menurunkan kualitas air permukaan yang digunakan sebagai air baku. Oleh karena itu pengolahan air limbah domestik sudah seharusnya dilakukan secara serius karena selain demi kesehatan manusia, efluen yang dihasilkan dapat dimanfaatkan kembali.

Pemenuhan kebutuhan air bersih dapat dilakukan dengan memanfaatkan kembali air limbah domestik (Erikkson,
2006). Air hasil olahan pengolahan air limbah domestik dapat digunakan kembali untuk kebutuhan proses produksi, menyiram tanaman, mencuci kendaraan, dan sebagai air gelontor. Pemanfaatan kembali dari efluen pengolahan air limbah domestik dapat menghemat penggunaan air bersih dari PDAM, sehingga dapat mengurangi pengeluaran finansial dari rumah tangga dan institusi. Proses pengolahan air limbah domestik dapat dilakukan secara biologis dengan Biofilter.

Teknologi Biofilter adalah suatu istilah dari reaktor pengolahan air limbah secara biologis dengan menumbuhkan mikroba pada suatu media membentuk lapisan biofilm. Mikroorganisme dalam biofilm ini mampu mendegradasi bahan organik (BOD) yang terlarut dalam air limbah.

\footnotetext{
*) Dosen Teknik Lingkungan

Universitas PGRI Adi Buana Surabaya
} 
Biofilter memiliki kemampuan yang sangat baik dalam mengolah air limbah domestik (Metcalf \& Eddy,2004). Pada penelitian ini dikembangkan Reaktor Biofilter untuk mengolah air limbah puskesmas (Ifadah dan Sugito, 2012) dengan mengacu pada criteria desain model IPAL yang telah dibuat sebelumnya, (Komariyah dan Sugito, 2011).

Pengolahan air limbah domestik dengan Biofilter aerobik menggunakan media pecahan batu kali diperoleh efisiensi penyisihan BOD sebesar $95 \%$ pada beban hidrolik $0,70 \mathrm{~m} 3 / \mathrm{m} 2$.hari dan beban organik 0,093 $\mathrm{kg} / \mathrm{m} 3$.hari (Sugito,2008). Pemanfaatan kombinasi Biofilter aerobik dan anaerobik untuk mengolah air limbah Puskesmas diperoleh penurunan yang sangat signifikan, yaitu konsentrasi BOD sebesar $8 \mathrm{mg} / \mathrm{l}$ pada efluen (Ifadah \& Sugito, 2012). Berdasarkan hal ini maka sangat memungkinkan dilakukan pengolahan efluen ini untuk memperoleh kembali air bersih. Untuk mengatasi kesulitan air bersih, maka perlu dilakukan penelitian pengolahan efluen produk pengolahan air limbah domestik dengan menggunakan teknologi filtrasi berbasis multimedia filter yang dilanjutkan dengan proses desinfeksi untuk menghilangkan mikroorganisme.

Hasil penelitian Sugito dan AlKholif (2012) tentang aplikasi Biofilter dan Filtrasi menunjukkan kinerja yang sangat baik untuk menghasilkan air bersih yang memenuhi standar. Air olahan sangat memungkinkan untuk digunakan sebagai air baku air minum, sehingga perlu dilakukan analisis lanjutan terhadap kualitas mikrobiologis. Parameter mikrobiologis merupakan aspek yang sangat penting diperhatikan untuk menurunkan jumlah kasus penyakit diare yang selalu terjadi terlebih pada saat terjadinya pencemaran air. Oleh karena itu perlu dilakukan proses desinfeksi untuk menurunkan kandungan total koliform sampai konsentrasi not available (NA), sehingga memenuhi standar kualitas air minum.

Proses desinfeksi merupakan metode untuk membunuh mikroorganisme yang tidak dikehendaki berada dalam air minum, seperti bakteri patogen sebagai penyebab berbagai penyakit, (Hadi. 2005, Said 2011). Desinfeksi merupakan benteng manusis terhadap paparan mikroorganisme patogen penyebab penyakit seperti bakteri, virus, dan protozoa. Untuk memenuhi pertimbangan praktis desinfeksi harus memenuhi persyaratan, diantaranya : 1)dapat membunuh berbagai jenis dan semua patogen yang ada di dalam air minum dalam waktu dan suhu tertentu, 2) desinfektan yang digunakan tidak beracun, 3) beaya pengadaannya murah, penyimpanannya aman, 4) kadar dalam air minum mudah dianalisis, 5) masih menyisakan sejumlah konsentrasi tertentu sebelum air dikonsumsi, (Fair, 1971).

Bahan kimia yang digunakan dalam proses desinfeksi adalah senyawa kelompok halogen. Faktor-faktor yang mempengaruhi efektivitas proses desinfeksi adalah : 1) jenis desinfektan, 2) jenis mikroorganisme, 3) konsentrasi dan lama waktu, 4) $\mathrm{pH}$, dan 5) temperatur. Berdasarkan kajian tersebut maka dalam penelitian ini digunakan bahan Kaporit. Hal ini didasarkan karena sifatnya yang sangat baik dalam meginaktivasi mikroorganisme dalam air.Kelarutan gas klor ke dalam air adalah $7300 \mathrm{mg} / \mathrm{L}$ pada suhu $68^{\circ} \mathrm{F}$ dan tekana $1 \mathrm{~atm}$. Di bawah suhu $49,2^{\circ} \mathrm{F}$, klor bebas bereaksi dengan membentuk es klorin, yang dapat merusak peralatan. Oleh karena itu suhu penguapan dan pencampurannya dengan air harus di atas suhu tersebut.

Kelemahan desinfeksi dengan menggunakan klor adalah terbentuknya senyawa trihalometan (THM) yang berbahaya. Oleh karena itu harus dilakukan treatment untuk dapat menghilangkan senyawa THM ini. Untuk itu dalam penelitian ini digunakan material karbon aktif sebagai media filtrasi yang dapat mengabsorbsi, sekaligus untuk menyerap bau dari air limbah sebagai air baku.

Berdasarkan uraian pada latar belakang di atas, maka permasalahan dalam penelitian ini adalah, "Bagaimanakah efisiensi penggunaan kaporit dalam menurunkan kandungan total koliform air olahan Biofilter terpadukan Filtrasi untuk menghasilkan air yang memenuhi standar kualitas air minum.

Tujuan penelitian adalah untuk mengkaji proses desinfeksi pada aplikasi Reaktor Biofilter terpadukan Teknologi Filtrasi berbasis media filter untuk memenuhi kebutuhan air minum dari bahan baku air limbah domestik.

Penelitian ini perlu dilakukan karena sangat bermanfaat bagi masyarakat diantaranya : 1). Kondisi air alami saat ini telah banyak terkontaminasi dengan berbagai bahan pencemar seperti ion ion polutan yang menjadikan air tidak aman lagi untuk dikonsumsi; 2). Meningkatnya kebutuhan air bersih akibat peningkatan jumlah penduduk, dan 3). Meningkatnya industri penghasil limbah cair domestik yang 
berpotensi mengandung pencemar serta ion

ion logam karena tidak melakukan pengolahan secara standar sehingga mencemari air permukaan yang digunakan sebagai air baku PDAM.

\section{METODOLOGI PENELITIAN}

Penelitian ini diawali dengan tes laboratorium tentang kandungan total koliform pada air hasil olahan Biofilter tanpa dilakukan desinfeksi. Hasil tes laboratorium diperoleh kandungan Fecal Coli sebesar $1880 / 100 \mathrm{ml}$ dan bakteri golongan Coli sebesar 2060/100 ml. Parameter ini harus diturunkan sampai batas sesuai dengan Baku Mutu Lingkungan (BML) dengan menggunakan treatment desinfeksi.

\section{Reaktor Percobaan}

Rangkaian reactor percobaan dalam penelitian ini terdiri dari dari 3 (tiga) tabung silindris yang tersusun seridengan sistem aliran up-flow downflow, dimana pada tabung pertama dilakukan treatment multi media filter berupa pasir silika, manganeese greensand, dan karbon aktif, tabung kedua dilakukan treatment ion exchange menggunakan resin sintetis anion, dan tabung ketiga merupakan perlakuan dengan resin kation. Treatment desinfeksi dilakukan pada bak clarifier reaktor biofilter sebelum air menuju reaktor filtrasi.

\section{Variabel Penelitian}

Variabel dalam penelitian ini terdiri dari :

1. Variabel bebas ; yaitu Konsentrasi Kaporit berturut turut : 100 ppm, 150 ppm, 200 ppm, 250 ppm. 300 ppm, 350 ppm, dan 400 ppm.

2. Variabel terikat : yaitu kualitas air olahan secara fisik, kimia dan biologis berupa bakteri Esherecia Coli

\section{Populasi dan Sampel}

1. Populasi dalam penelitian ini adalah air limbah terolah dalam reaktor Biofilter pada bak Clarifier dilanjutkan dengan media Filtrasi dan desinfeksi dengan kapasistas debit $6 \mathrm{M}^{2} /$ hari.

2. Sampel untuk setiap running percobaan penambahan Kaporit secara kontiyu melewati reaktor Filtrasi dalam penelitian ini adalah air olahan pada bak Clarifier sebanyak $1 \mathrm{M}^{2}$. Dari air olahan terakhir setelah melewati pengolahan lengkap selanjutnya diambil masingmasing $1.500 \mathrm{ml}$ setiap kali running percobaan untuk dilakukan analisis kualitas lengkap untuk parameter fisik, kimia dan mikrobiologis di laboratorium.

\section{Alat dan Bahan Penelitian}

Alat alat yang digunakan dalam penelitian ini adalah sebagai berikut : Reaktor Biofilter,kran $\varnothing \quad 1 / 2$ ",pipa $\varnothing$ 1/2”, pipa PVC $\varnothing$ 4“ , Ø 6“, Ø 8“, Рipa PVC, Jirigen, Lem PVC, Tandon, air limbah, Pompa, dan Perangkat alat analisis parameter air bersih

Bahan-bahan yang digunakan dalam penelitian ini adalah sebagai berikut : Resin kation dan anion, Reagen analisi BOD, aquadest , Pasir silika, Manganeese Greensand, Karbon aktif, dan Kaporit

\section{Prosedur Percobaan}

Langkah-langkah dalam penelitian ini dilakukan sebagai berikut:

1. Mengoperasikan reactor Biofilter dengan bahan baku air limbah domestic dari puskesmas dengan debit $6 \mathrm{~m}^{3}$ / hari

2. Menambahkan kaporit pada bak clarifier dengan dosis mulai dari konsentrasi terendah sebesar 100 ppm dan dilakukan pengadukan

3. Memompa air olahan dari bak clarifier menuju reactor filtrasi yang berisi multi media filtrasi dengan aliran upflow-downflow agar diperoleh air olahan yang sangat baik

4. Mengambil sampel air yang keluar dari reactor filtrasi terakhir untuk dilakukan pengujian parameter kualitas air bersih

5. Menguji kualitas air terolah secara fisis, kimia, dan biologis berupa Esherecia Coli di Laboratorium dengan metode mengacu Standart Methods APHA AWWA 2008, (Alaerts dan Sumestri, 2008)

6. Menganalisis data percobaan berupa parameter kualitas air dengan menggunakan diagram dan grafik untuk mengkaji pengaruh penggunaan dosis kaporit.

\section{HASIL PENELITIAN DAN PEMBAHASAN}

Hasil analisis uji laboratorium untuk parameter Esherecia Coli setelah dilakukan treatment filtrasi dan Desinfeksi dengan menggunakan berbagai variasi dosis kaporit disajikan pada gambar 1. sebagai berikut : 


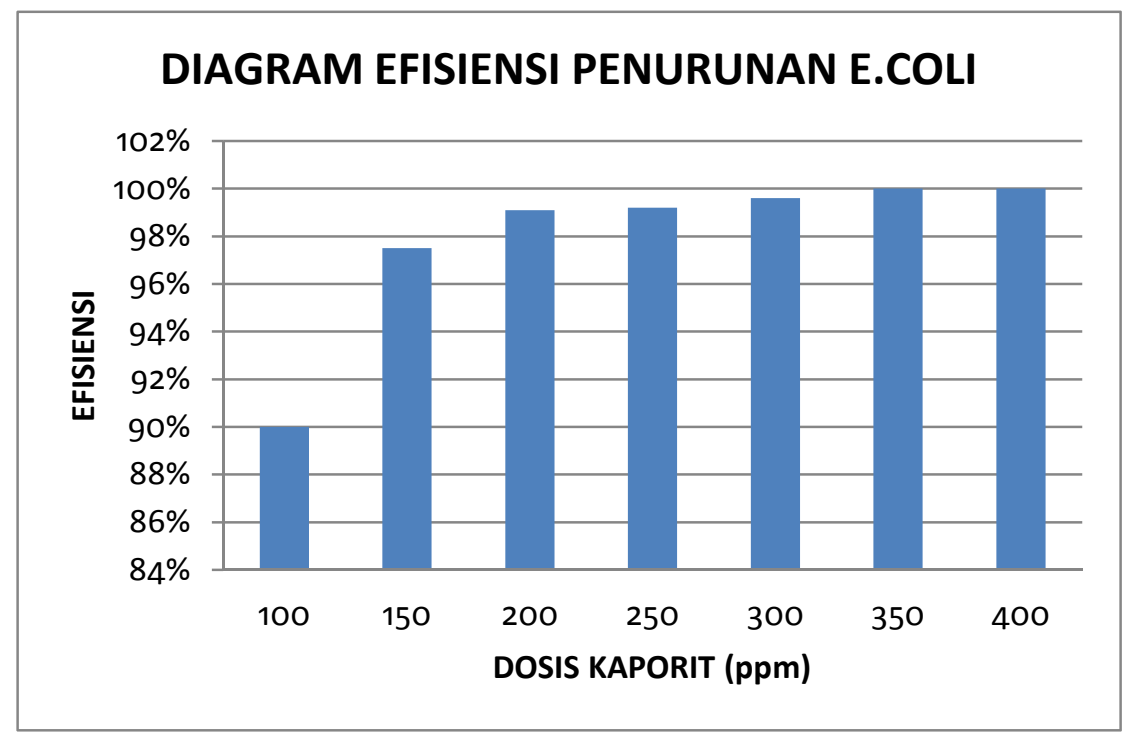

Gambar 1. Diagram Efisiensi Penurunan E-Coli

Gambar 2.a. dan 2.b. menunjukkan konsentrasi parameter air bersih berupa kation dan anion setelah proses pengolahan lengkap dengan Biofilter, Filtrasi dan Desinfeksi. Beberapa parameter anion yang terdeteksi dengan konsentrasi kecil adalah sulfat, klorida, nitrat, flourida dengan hasil jauh di bawah ambang batas yang ditetapkan oleh Permenkes tentang kualitas air bersih. Konsentrasi kation diwakili oleh kandungan Besi dan Seng juga sangat memenuhi syarat sebagai air bersih yang dapat dimanfaatkan kembali.

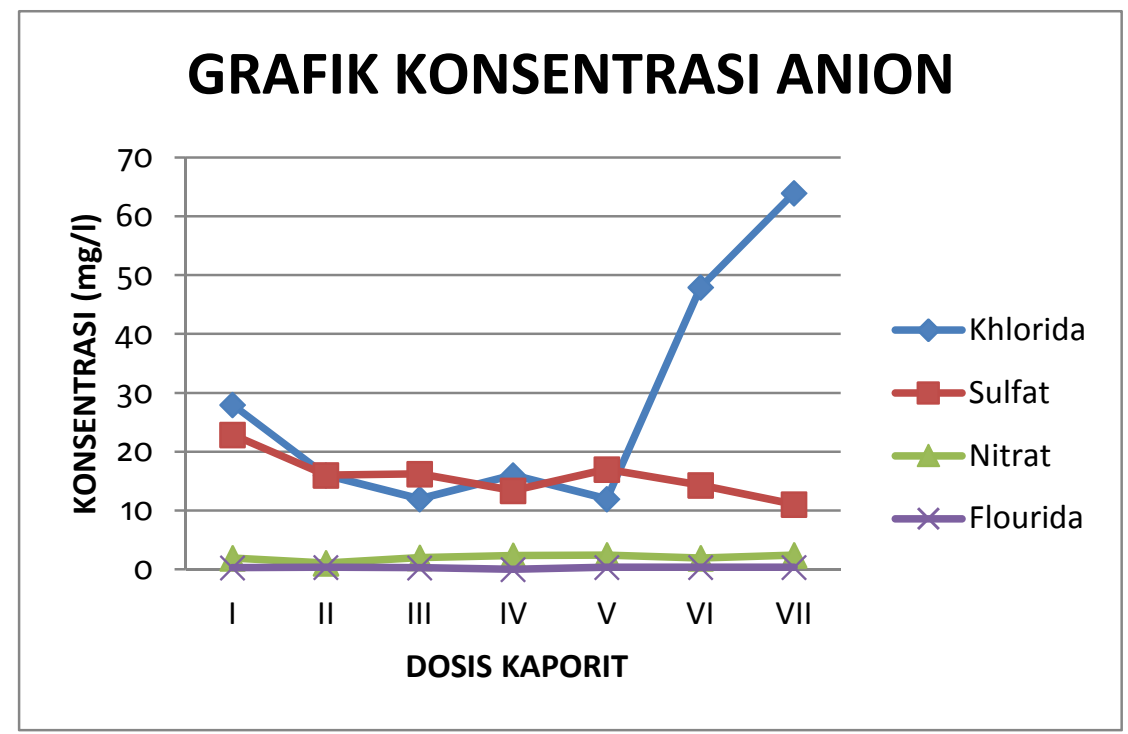

Gambar 2.a. Konsentrasi anion pada berbagai variasi dosis kaporit 


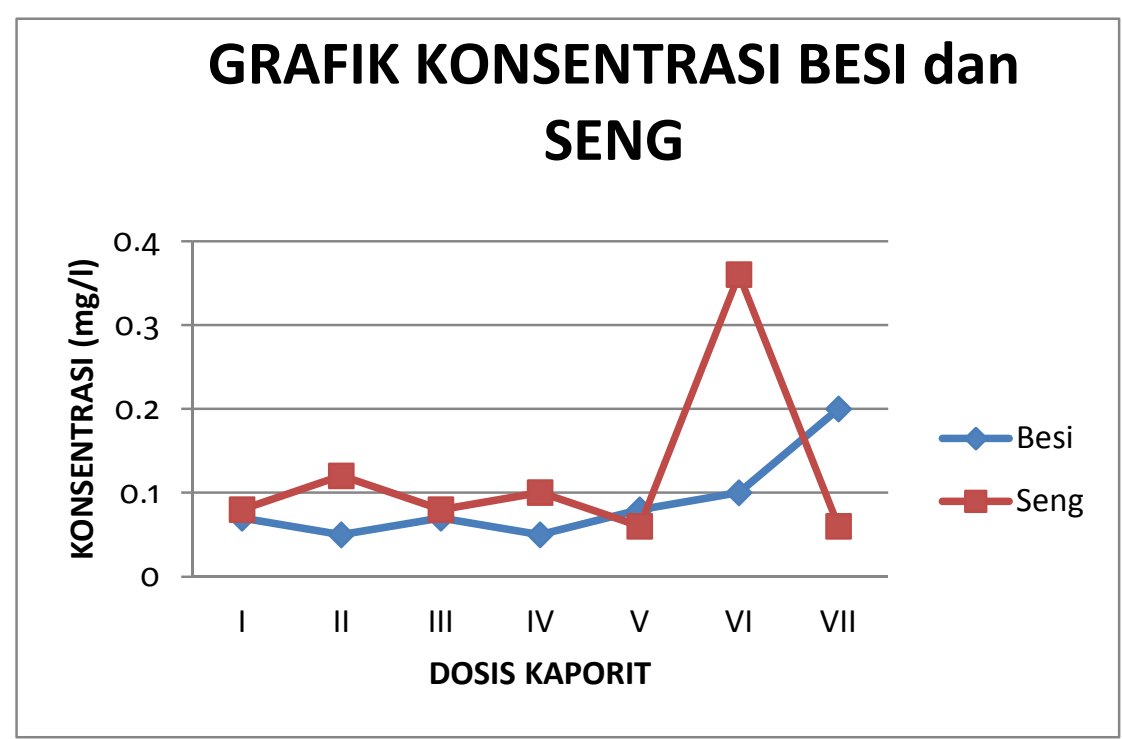

Gambar 2.b. Konsentrasi ion Besi dan Seng pada berbagai konsentrasi dosis kaporit

Secara umum dapat dikatakan bahwa konsentrasi nanion klorida, sulfat, flourida, dan nitrat berapa pada konsentrasi yang sangat aman dibandingkan dengan BML kualitas air bersih. Pada penambahan kaporit mulai dari dosis 150 ppm sampai dengan 400 ppm konsentrasi anion semuanya berada di bawah $20 \mathrm{ppm}$. Peningkatan klorida pada penambahan kaporit dengan dosis 350 dan 400 ppm mengalami kenaikan disebabkan karena kandungan atom Khlor dalam kaporit yang lepas menjadi anion khlorida.

Berdasarkan hasil penelitian di atas selanjutnya dilakukan kajian antara influen yakni air olahan biofilter terhadap efluen terolah setelah proses desinfeksi dan treatment dengan multimedia gabungan antara pasir silika, manganese greensand, karbon aktif, dan media resin.

\section{a. Parameter Fisis}

Secara fisik air olahan teknologi filtrasi menghasilkan air yang sangat jernih sehingga sangat layak digunakan sebagai air bersih. Produk air hasil filtrasi tidak berwarna, tidak berbau, dan tidak berasa. Bau limbah awal direduksi oleh media filter yaitu penggunaan karbon aktif. Media ini melakukan absorbsi secara efektif. Parameter kekeruhan air hasil olahan adalah sangat kecil dibandingkan dengan baku mutu yang ditetapkan sebesar 25 NTU. Kinerja media filtrasi terhadap kekeruhan dapat meremoval sebesar $70 \%$ terjadi pada perpaduan dengan penambahan kaporit sebesar 250 ppm. Parameter Zat padat juga menunjukkan angka yang memenuhi syarat sebagai air bersih.

\section{b. Parameter Kimiawi}

Secara umum semua parameter kimia menunjukkan bahwa air olahan sangat layak digunakan sebagai air bersih dan air baku air minum. Media filter berfungsi secara efektif meremoval kandungan kimiawi dalam air. Kinerja resin sangat efektif dalam dapat menurunkan ion Kalsium dalam bentuk kesadahan sebesar $90 \%$ pada perpaduan penambahan kaporit sebesar $300 \mathrm{ppm}$, namun ion kalsium mengalami kenaikan seiring dengan penambahan kaporit yang semakin besar pada penambahan $350 \mathrm{ppm}$ dan 400 ppm. Hal ini dimungkinkan karena peningkatan konsentrasi kalcium yang terkandung dalam kaporit Parameter logam $\mathrm{Fe}$ sangat memenuhi syarat sebagai air bersih, (gambar 2.b.), hanya sebesar 5\% dari baku mutu yang ditetapkan, sedangkan logam Zn sebesar 0,4\%. Parameter Sulfat, Klorida, Nitrat, dan Flourida semuanya sangat memenuhi syarat baku mutu karena konsentrasinya jauh di bawah baku mutu yang ditetapkan seperti gambar 2.a.

\section{c. Parameter Mikrobiologis}

Air olahan sudah tidak mengandung koliform dalam penelitian ini. Konsentrasi total koliform pada air olahan mencapai 0 MPN/100 mL pada penambahan kaporit dengan dosis 350 ppm dan 400 ppm. Seperti yang dibahas dalam kajian teori bahwa penggunaan senyawa desinfektan kaporit sangat efektif dalam menurunkan mokroorganisme. 


\begin{abstract}
Senyawa klor memiliki kelarutan yang sangat baik, sehingga mampu membunuh bakteri Esherecia Coli yang terlarut dalam air. Angka ini sangat memenuhi syarat sebagai air bersih dan selanjutnya dapat dipertimbangkan menjadi air baku untuk air minum dengan pengolahan lanjut.

Perpaduan teknologi Biofilter dan Filtrasi berbasis multimedia filter dan desinfeksi menggunakan kaporit dapat mengolah air limbah domestik menjadi air bersih yang memenuhi syarat baku mutu lingkungan yang ditetapkan oleh Permenkes RI No : 416/MENKES/PER/IX/1990. Teknologi ini terbukti mampu menghasilkan air olahan yang sangat baik sehingga dapat dimanfaatkan kembali dan sangat memungkinkan digunakan sebagai air baku air minum. Perlu dilakukan penelitian lanjutan agar air terolah dimanfaatkan sebagai air minum sehingga dapat menekan biaya penggunaan air dan kontinuitas penggunaan air bersih serta air minum tetap terjaga. Pada akhirnya air limbah tidak menjadi masalah lagi namun dapat dimanfaatkan kembali (recycle) untuk menghindari pencemaran lingkungan akibat timbulan pencemar air limbah domestik dari berbagai sumber.
\end{abstract}

\section{KESIMPULAN DAN SARAN \\ Kesimpulan}

Kinerja media filtrasi perpaduan pasir silika, manganess greensand, karbon aktif dan resin untuk mengolah air olahan Biofilter mampu menghasilkan air bersih yang memenuhi standart kualitas dari aspek fisik dan kimiawi dan biologis, seperti yang ditetapkan oleh Permenkes RI No : 416/MENKES/PER/IX/1990. Proses desinfeksi menggunakan kaporit dalam penelitian ini menghasilkan kualitas air dengan parameter mikrobiologis E. Coli sebesar 0 MPN/ $100 \mathrm{~mL}$ terjadi pada penambahan dosis kaporit sebesar 350 ppm dan 400 ppm. Air olahan dari air limbah domestik dalam penelitian ini direkomendasikan dapat digunakan sebagai air baku air minum dengan proses lanjut.

\section{Saran}

Perlu dilakukan penelitian lanjutan untuk menguji parameter kualitas air sehingga produk air olahan siap digunakan sebagai air minum.

\section{Ucapan Terima Kasih}

Penulis mengucapkan terima kasih sebesar-besarnya kepada Rektor dan Kepala LPPM Universitas PGRI Adi Buana Surabaya yang telah memberikan kesempatan untuk melaksanakan penelitian melalui program Hibah Adi Buana berdasarkan surat kontrak Kepala LPPM No. 120.a.58/LPPM/VI/2013 tanggal 5 Juni 2013

\section{DAFTAR PUSTAKA}

Alaerts, G. dan Sumestri, S, (1987), Metode Penelitian Air, Usaha Nasional, Surabaya.

APHA, AWWA, (1998), Standard Methods for the Examination of Water and Wasterwater, $20^{\text {th }}$ Edition, Washington.

Eriksson, E. et.al, (2006), Phytotoxicity of Grey Wastewater Evaluated by toxicity test, Urban Water Journal, Vol.3, No.3, hal. $13-20$.

Hadi, Wahyono.2005. Perencanaan Bangunan Pengolahan Air Minum. FTSP ITS Surabaya.

Hermana, 2008, Keberlanjutan Sistem Pengelolaan Sanitasi Perkotaan dalam Perspektif Rekayasa IImu Perencanaan Bangunan Pengolahan di Indonesia, FTSP ITS Surabaya

Ifadah, Siti M, \& Sugito ( 2012), Kinerja IPAL Biofilter untuk Pengolahan Air Limbah Domestik di UPT Puskesmas Janti Kota Malang. Prosiding Semnas Teknoin UII 2012, hal A93-A100, tanggal10 November 2012

Komariyah, S. Dan Sugito. 2011. Perencanaan Biofilter di UPTD Kesehatan Puskesmas Gondang Wetan Kabupaten Pasuruan. Jurnal Teknik WAKTU, ISSN: 1412-1867 volume 11 Nomor 01-Januari 2012

Metcalf \& Eddy, (2004), Wastewater Engineering Treatment and Reuse, Fourth Editioan, McGrawHill Inc, New York.

Reynold, T.D. \& Richards P.A, (1996), Unit Operations and Processes in Environmental Engineering, PWS Publishng Compeny. 
Said,Nusa Idaman (2006), Teknologi Pengolahan Limbah Cair Sistem Biakan Melekat (Rumah Sakit, Domestik, Industri). Pusat Teknologi Lingkungan, Jakarta.

Sall, O. \& Takahashi, Y, (2006), Physical, Chemical, \& Biologycal Characteristics Of Stored Grey Water from Unsewered Suburban Dakar In Senegal, Urban Water Journal, Vol.3, No. 3, hal. 153-164.

Sugito, dan Masrul, (2007). Perencanaan IPAL Biofilter Untuk Pengolahan Limbah Cair Industri Tempe. Jurnal Teknik WAKTU, ISSN : 1412-1867 volume 05 Nomor 02-Juli 2007

Sugito, (2008), Pengaruh Beban Hidrolik dan Beban Organik pada Kinerja Biofilter Aerobik untuk Pengolahan Grey Water Kota Surabaya, Proceeding Of the 7th National Conference, Design and Aplication of Technology, UWM ISSN 1412-727 X , hal 91-98

Sugito, (2012) Pengembangan Reaktor Biofilter Terpadukan dengan Teknologi Filtrasi untuk Mengolah air Limbah Domestik Menjadi Air Bersih. Jurnal WAHANA, ISSN : 0853-4403, Volume 59 No 2 hal 37-43, 1 Desember 2012. 